\title{
Юрій Борейко
}

\section{Ідентичність православних віруючих у сучасній Україні}

3'ясовується специфіка розвитку ідентичності православних віруючих у сучасному українському суспільстві. Обгрунтовано твердження, що їхня ідентичність характеризується нашаруванням кількох самототожностей, поєднуючи релігійний і культурний компоненти. Визначено, що проблеми самоідентифікації православних в Україні зумовлені головним чином інституційним поділом, який має цивілізаційний вимір. Встановлено, що основним фактором, що впливає на розвиток ідентичності віруючих на сучасному етапі, є створення помісної Православної церкви України.

Ключові слова: конфесійна ідентичність, православний віруючий, українське суспільство, традиція, православна юрисдикція, релігійна громада, культурна ідентичність

Сучасні події, що пов’язані з процесом створення Православної церкви України, актуалізують важливість дослідження конфесійної ідентичності українських православних віруючих. Особливого значення набувають питання, які стосуються динаміки української православної ідентичності, детермінант змін у конфесійному самовизначенні, співвідношення конфесійної ідентифікації та конфесійної належності. У цьому контексті дослідницької уваги потребує з'ясування специфіки самоідентифікації українських вірян православних юрисдикцій на основі громадянської позиції та бачення цивілізаційного вектора розвитку країни. Глибоке осмислення зазначених питань неможливе без врахування соціальної природи ідентичності, тобто аналізу цього феномена через призму його соціальних детермінант, у т. ч. стратегій повсякденної поведінки віруючої особи.

Проблеми національної, культурної та релігійної самототожності, особливості вияву конфесійності в умовах відкритого соціуму, сутність і роль релігійних ідентичностей у розбудові громадянського суспільства та пошуки нової релігійної ідентичності, обумовленої поліконфесійністю суспільного середовища, досліджують А. Арістова, М. Бабій, 3. Бауман, П. Бергер, В. Сленський, А. Забіяко, С. Здіорук, О. Крилов, А. Колодний, Н. Мадей, М. Мчедлов, І. Папаяні, О. Саган, 
Л. Филипович, М. Черенков, Н. Черниш, Ю. Чорноморець, В. Шевченко, І. Яблоков, П. Яроцький та інші. Незважаючи на вагомі здобутки вчених, усе ще недостатньо вивченою залишається проблематика розвитку конфесійної ідентичності українських носіїв православної свідомості.

Отже, метою статті є висвітлення особливостей розвитку ідентичності православних віруючих в Україні на теперішньому етапі.

Віруюча особа усвідомлює власну самототожність за допомогою релігійних постулатів та норм, які стають посередником ідентифікаційних процесів, полегшують пошук відповідей на екзистенційні питання, збереження та передачу конфесійної традиції. Ідентичність вірянина формується шляхом усвідомлення тотожності та відмінності, належності до певної спільноти й відособленості від представників інших спільнот.

Таку ідентичність можна розглядати в широкому спектрі - i як організацію життєвого досвіду в індивідуальному Я, і як детерміновану колишнім досвідом даність, що зберігає значущість для нащадків, і як відображення внутрішньої тотожності людини із соціальними ідеалами і стандартами, і як самопов'язування ії 3 певною церковно-релігійною традицією. Очевидно, що євроінтеграційна стратегія України охоплює й духовну сферу, що, власне, також спонукає нас до вивчення ідентичності, зокрема релігійної. Суттєвим моментом $€$ й той факт, що поєднання майбутнього України з Свропою має супроводжуватися зростанням національної самоповаги. На сучасному етапі ідентифікаційна суперечливість поліконфесійного українського суспільства згладжується законодавчим забезпеченням рівності всіх релігійних організацій на засадах демократичних цінностей $[1$, с. 288$]$.

Як констатують дослідники, на відміну від більшості європейських народів українці сьогодні перебувають на межі між втраченою макро- (радянською) і ненабутою мікро- (національною) ідентичностями. Самовизначення українців у параметрах макропріоритетів виявляється у формі проєвропейського або проросійського дискурсів розвитку. Цей процес ускладнюється й тим, що в сучасному світі, з одного боку, відбувається розмивання національного та релігійного, а з іншого боку, етнорелігійна ідентифікація й надалі відіграє важливу суспільну роль [2].

Релігійна ідентичність - це не лише належність індивіда до певної соціальної групи, зокрема релігійної громади, а й усвідомлення або переживання цієї належності. Конструювання такої самототожності на рівні особистості та спільноти здійснюється завдяки культовим та білярелігійним практикам шляхом інтеграції соціокультурних тенденцій суспільства і сприйняття релігійного вчення. Завдяки цьому стає можливою фіксація, актуалізація та визначення особистістю і спільнотою свого місця в суспільному просторі [3].

Формування релігійної ідентичності, за оцінкою вчених, передбачає наявність релігійних знань, цінностей та відповідної поведінки. Релігійна спільнота повинна мати власні знання, пам'ять про себе, версію бачення себе як громади вірян, 
однакові для всіх їі членів базові цінності, характерний стиль поведінки, котрий засвідчує їхню спільність. Аналіз трансформації ідентичностей в українському православ'ї засвідчує спроби Православних церков сформувати єдину українську ідентичність на підставі євхаристійної еклезіології, що станом на сьогодні не увінчалося успіхом [4].

Сучасні проблеми конфесійної ідентичності в Україні зумовлюються, серед іншого, перехідним станом суспільства, що є основою поліваріантності самоідентифікацій людини. Внаслідок цього відбувається ототожнення релігійної та національно-державної ідентифікації. Дослідники пояснюють цей феномен тим, що в Україні не домінує жодна з християнських конфесій, а релігійне життя детермінується процесами самовідтворення, взаємною толерантністю релігійних спільнот та узгодженням ними своїх інтересів [5, с. 165].

Існує думка, що для українського суспільства найбільш прийнятною є багатовимірна національна ідентичність громадянсько-політичного типу, яка охоплює етнічну, мовну, релігійну, регіональну, професійну, класову, вікову, статеву та інші тотожності. Розвиток релігійної, національної та європейської ідентичності громадян України вимагає низки передумов, як-от захист українського інформаційного простору, підвищення політичної культури громадян тощо [6].

Якщо конфесійне самоототожнення громади візуалізується насамперед через відповідний спосіб життя, то суб’єктна значущість цієї тотожності виявляється на значно глибшому рівні, визначаючи систему цінностей особи, різноманітні життєві вибори, під впливом котрих соціальна ідентичність віруючого набуває релігійного вигляду в усіх аспектах, включаючи й громадянський. Домінантний вплив духовних цінностей на форми соціальної поведінки й унезалежнення цих цінностей від зміни політичної ситуації є головними умовами розвитку детермінованої релігією громадянської ідентичності.

Безсумнівно, що конфесійна ідентичність твориться у взаємодії з іншими. Іноді така взаємодія має конфліктний характер, що істотно впливає на конфесійне самовизначення особи, їі ціннісні орієнтації, світоглядні пріоритети, релігієвибір, позацерковне буття, довіру до релігійних організацій та служителів культу, ставлення до представників інших релігійних чи конфесійних ідентичностей. Так, вкоріненість в ідеологію “русского мира" і проросійська орієнтація частини ієрархів УПЦ МП суттєво перешкоджає об’єднанню всіх віруючих під егідою нової Церкви.

Створення Православної церкви України викликає неоднозначні оцінки з боку кліру, мирян, експертного середовища. Існують діаметрально протилежні підходи - від твердження про автокефалію як єдину можливість досягти єдності та визнання українського православ'я до обгрунтування передвиборчого характеру дій влади. Опозиційні депутати акцентують увагу на необхідності вирішення таких питань не в межах політичної парадигми, а в рамках міжцерковного діалогу. Церковні кола УПЦ МП заявляють про грубе втручання держави у внутрішні справи Церкви. За таких обставин, на наш погляд, інтегральною ідентичністю, 
зокрема для православних вірян, повинна стати християнська ідентичність, яка передбачає співвіднесення віруючого зі знаково-символічним, ідейно-образним та ціннісно-смисловим простором християнства.

Осередком становлення конфесійної ідентичності особи є релігійна громада, в якій організовується середовище для взаємодії вірян. Згідно $з$ дослідженнями різних учених, саме місцеві громади, котрі репрезентують первинний рівень діяльності певної релігійної організації, впливають на буденну свідомість віруючих, визначають тип зв’язку особи з релігійною організацією, сприяють відтворенню релігійності, формують громадську думку щодо конфесії та ступеня дотримання віровчення іï послідовниками. Важливим є висновок про те, що усвідомлення необхідності активної ролі місцевої громади як первинного осередку інституційної структури конфесії базується на з'ясуванні механізму поширення релігійних ідей у суспільстві, їхнього впливу на віруючих [7, с. 548-552].

У цих умовах на формування ідентичності православних значною мірою впливає функціонування біляцерковних спільнот. Дослідники аналізують напрями їхньої діяльності, діапазон світоглядних орієнтирів, характер співпраці з Церквами та релігійними організаціями, ступінь впливу на одновірців та суспільство загалом, склад біляцерковних структур, особливості громадянської позиції їхніх членів. За нинішньої релігійної, правової та політичної ситуації в Україні релігійні організації виразно зацікавлені у функціонуванні таких спільнот. Завдяки мобільності та згуртованості своїх переконаних послідовників, їхній активності в Церкві й суспільстві, біляцерковні спільноти помітно вирізняються на тлі інертності основної маси парафіян, релігійність котрих, як правило, зводиться до обрядовір'я [8].

Оскільки залучення до спілкування та спільної діяльності є чи не найдієвішим способом громадянського і християнського виховання, то особливого значення, на думку Ю. Чорноморця, набуває соціальне служіння як громадських організацій, так і Церков. За оцінкою вченого, відбувається зближення загальних завдань виховання молоді з актуальними потребами християнської Церкви. 3 огляду на це, і суспільство, і Церкви й надалі виявлятимуть зацікавлення в діяльності християнських молодіжних організацій, з більшим розумінням ставлячись до служіння цих спільнот, залучення молоді до комунікації [9].

Сьогодні в Україні спостерігається підвищений рівень декларованої релігійності та активізація процесів самовизначення православних вірян у межах церковноконфесійної належності. Проте така самоідентифікація не завжди означає реальну участь віруючого у функціонуванні однісї з релігійних громад. Навіть більше, конфесійне самовизначення часто стає компонентом соціокультурного, етнічного чи ідеологічного самоототожнення, що є відповіддю на суспільно-політичні та соціально-економічні виклики сучасного українського суспільства. На це вказує хоча б часте самодекларування православної ідентичності, яке не підтверджується активним виконанням релігійних практик. 
Аналіз особливостей розвитку православної ідентичності доводить, що в Україні переважає модальний тип віруючого, для котрого притаманні позаконфесійність і позацерковність, що нерідко зводяться до превалювання форми над змістом релігійності. Життя в релігійній спільноті характеризується низькою інтенсивністю, слабким зв'язком вірян зі своєю громадою, якій подекуди властиві ізоляція та перехід у субкультурність. Це ускладнює задоволення потреби у вірі, сприяє поширенню нових форм релігійності. Більшість віруючих мають еклектичні та синкретичні релігійні уявлення, вони недостатньо обізнані $з$ догматами віри і зберігають у свідомості цілий пласт позацерковної релігійності $[10$, c. 206].

Отже, в сучасних українських реаліях самовизначення “я православний християнин” має значно вужчий вияв, ніж “я православний віруючий”, тому православна ідентичність українських вірян виявляє чимало рис культурної ідентичності. Людина часто вважає себе православною не стільки тому, що вона вірить у Бога, скільки тому, що хрещена і є громадянином країни з православними традиціями, завдяки яким, поряд із національною культурою, відчуває духовну спорідненість і з Церквою.

За результатами проведеного Центром Разумкова в квітні 2018 р. соціологічного дослідження, 67,3 \% опитаних відносять себе до православ'я. Серед тих, хто називає себе православним віруючим, число прихильників УПЦ КП перевищує число вірних УПЦ МП - 42,6 \% проти 19,1 \% відповідно, до УАПЦ належать 0,4 \% респондентів. При цьому таке самовизначення не завжди пов'язане з реальним залученням особи до діяльності однісї з релігійних спільнот. Узявши до уваги перевагу УПЦ МП над УПЦ КП у чисельності громад, можемо зробити висновок про схильність віруючих декларувати конфесійну належність до тієї юрисдикції, яка має суспільну підтримку.

Існує також багато осіб, котрі іменують себе “просто православними”. Привертає увагу зменшення частки цієї категорії серед усіх респондентів - з 39,8 \% у 2014 р. до 34,8 \% у 2018 р. [11, с. 17]. Така тенденція до зниження кількості “просто православних" пояснюється, вочевидь, їхнім церковним визначенням на користь УПЦ КП (42,6 \% у 2018 р. проти 31,9 \% у 2014 р.). 3 іншого боку, усе ще значна численність цієї групи опитаних $є$ результатом самоототожнення 3 культурною традицією країни.

Подібна тенденція простежується й щодо ставлення громадян до створення помісної Православної церкви України. Як показало загальнонаціональне дослідження, організоване соціологічною службою Центру Разумкова разом із Фондом “Демократичні ініціативи” ім. Ілька Кучеріва в грудні 2018 р., 43 \% громадян виступають за створення в Україні помісної автокефальної Православної церкви, $22 \%$ - проти. Прикметно, що число тих, хто висловив свою підтримку, порівняно 3 травнем 2018 р. (31 \% респондентів), істотно зросло. Це відбулося, мабуть, за рахунок скорочення частки тих, кого ця проблема не цікавить, і тих, хто не визна- 
чився, - їх сумарна кількість знизилася за період з травня по грудень із 49 \% до 35 \%. Частка тих, хто не підтримує появу цієї Церкви, не зазнала істотних змін (20\% - у травні, $22 \%$ - у грудні) [12].

Загалом сучасна ідентифікація православних віруючих характеризується стійкою тенденцією до переважання культурного чинника. Самовизначення українських православних зміщується в бік культурної ідентичності через ідеологічний вакуум у суспільстві, слабкість громадянської свідомості, виклики глобалізації та радянську атеїстичну спадщину. Вагомим чинником є також історична пам'ять, згідно з якою ця самототожність уважається традиційною, хоча насправді вона суттєво трансформується.

Як бачимо, православна ідентичність у сучасній Україні має щонайменше два пласти. Культурні ознаки (відзначення релігійних свят, носіння хрестика, виконання певних обрядів тощо) творять зовнішню оболонку, дотичну iз соціумом. Натомість власне релігійна складова (комплекс психологічних переживань, пов'язаний із раціональним та ірраціональним досвідом осягнення християнського Бога) перебуває в латентному стані, становлячи сакральне ядро нової тотожності. Відтак сучасна православна ідентичність може розвиватися як назовні, в напрямку комунікацій із суспільством, так і всередину - у бік набуття індивідуального містичного християнського досвіду.

Відштовхуючись від ідеї взаємодоповнення і взаємозв'язку цих двох пластів конфесійної тотожності, виокремимо кілька ії типів, що представлені в нинішньому українському суспільстві. Так, позаінституційна православна ідентичність грунтується на самовизначенні стихійних віруючих і неоцерковлених християн, основною рисою котрих є відмова від інституалізації.

Групова православна ідентичність виникає внаслідок соціалізації в православній спільноті шляхом прищеплення новим адептам норм віросповідання та відповідного способу життя і поведінки. Завдяки своїм інституційним рамкам, вона забезпечує відчуття захищеності, оскільки дає змогу реалізувати численні соціальні та екзистенціальні потреби людини. Зазвичай у конфесійній тотожності цього типу релігійний досвід не становить іiї головного змісту.

Формування індивідуально-особистісної православної ідентичності відбувається в результаті індивідуального спілкування з Богом. Це сфера містичного християнства, збагачена елементами досвіду, що викладений у творах отців Церкви, та власними намаганнями віруючого йти шляхом досягнення аскетичного християнського ідеалу. Основою цього типу релігійної тотожності є освячене вченням та переданням самообмеження, тому їі ще можна назвати аскетичною або містичною православною ідентичністю.

Нарешті, соціально-особистісна православна ідентичність є простором соціальності особистості. Ї̈ характерна ознака - відкритість до суспільних взаємодій, прийняття світу в його різноманітності. Така тотожність окреслюється в ситуації, коли людина усвідомлює особистий шлях активної соціальної діяльності. Без- 
умовно, що всі перелічені типи православної ідентичності доповнюють один одного. Позаінституційна ідентичність віруючої особи, наприклад, здатна еволюціонувати до групової або змінюватися з аскетичної на соціально-особистісну $[13$, с. 63-64].

Визнання належності до культури, що супроводжується осмисленням шляхів iii розвитку, свідчить про актуалізацію національної ідентичності громадянського типу, яка не тільки виступає певним способом ставлення до влади, а має ширший зміст - належність до національної держави. Оцерковлення як православна форма релігійної соціалізації в церковній спільноті через засвоєння релігійних практик і прийняття ідентичності парафіянина певного храму в цьому контексті постає не лише процесом становлення конфесійної ідентичності, а й набуття або зміни громадянської ідентичності. Щобільше, громадянський компонент православної ідентичності може переважати над релігійним або й взагалі обходитися без нього, що помічаємо в середовищі віруючих на сучасному етапі.

Таким чином, у конфесійному самовизначенні значної кількості православних віруючих істотне значення має національно-культурний компонент. Релігійна складова православної ідентичності, що виявляється в особистому ставленні до християнських цінностей, є світоглядною основою церковно-конфесійного самовизначення. Для частини вірян конфесійне самоототожнення означає прийняття відповідного способу життя, системи цінностей, під впливом яких їхня соціальна ідентичність набуває релігійного забарвлення. Взаємодоповнення релігійного і культурного пластів ідентичності українських православних дає змогу виокремити позаінституційний, груповий, індивідуально-особистісний і соціально-особистісний типи православної ідентичності. Потужним поштовхом для іï формування є створення помісної Православної церкви України.

1. Шевченко В. В. Православ'я в Україні і цивілізаційні виклики: історія та сучасність. Київ: Видавничий відділ УПЦ Київського Патріархату, 2013. 639 с.

2. Филипович Л. О. Етнорелігійна ідентичність: визначення і збереження // Українське релігієзнавство. 2010. № 56. С. 228-237.

3. Папаяні I. В. Феномен релігійної ідентичності в контексті філософсько-релігієзнавчого дискурсу: дис. ... канд. філос. наук. Донецьк, 2010. 207 с.

4. Чорноморець Ю. Сучасні проблеми з релігійною ідентичністю: трагедія православ'я. URL: ttps://risu.org.ua/article_print.php?id=42544\&name=society_digest\&_lang=ua\& (дата звернення - 26.01.2019).

5. Мадей Н. Феномен конфесійної ідентичності в українському суспільстві // Духовність. Культура. Нація: зб. наук. ст. Львів: Видавничий центр ЛНУ імені Івана Франка, 2009. Вип. 4. C. $158-165$.

6. Воропаєва Т. Формування національної та релігійної ідентичності громадян України (1993-2010). URL: http//www.etnolog.org.ua/index.php?option=com_content\&task=view\&id=107 (дата звернення - 26.01.2019).

7. Академічне релігієзнавство: підручник / за наук. ред. проф. А. Колодного. Київ: Світ Знань, 2000. 862 с. 
8. Климов В. Зростання ролі біляцерковних спільнот в житті традиційних церков // Українське релігієзнавство. 2008. № 48. С. 198-215.

9. Чорноморець Ю. Християнська молодіжна організація на початку 21 століття: нові можливості для вирішення вічних проблем. URL: www.religion.in.ua/.../15205-xristiyanskamolodizhna-organizaciya-na-pochatku-21-stolitti-novi-mozhlivosti-dlya-virishennya-vichnixproble... (дата звернення - 26.01.2019).

10. Борейко Ю. Повсякденність українського православного вірянина: монографія. Луцьк: Вежа-Друк, 2016. 380 с.

11. Особливості релігійного і церковно-релігійного самовизначення українських громадян: тенденції 2010-2018pp. Інформаційні матеріали до Круглого столу “Релігія і влада в Україні: проблеми взаємовідносин”, 26 квіт. 2018 р. Київ: Центр Разумкова, 2018. 78 с.

12. Динаміка ставлення громадян України до створення помісної автокефальної православної церкви. URL: http://razumkov.org.ua/napriamky/sotsiologichni-doslidzhennia/dynamikastavlennia-gromadian-ukrainy-do-stvorennia-pomisnoi-avtokefalnoi-pravoslavnoi-tserkvy (дата звернення - 29.01.2019).

13. Борейко Ю. Г. Національний чинник у формуванні православної ідентичності в сучасному українському суспільстві // Наукові записки Національного університету “Острозька академія". Серія “Історичне релігієзнавство". Острог : В-во Національного університету “Острозька академія”. Вип. 12. С. 57-67.

\section{SUMMARY}

\section{Identity of Orthodox believers in modern Ukraine}

Yurii Boreiko

The features of the development of Orthodox believers' identity in modern Ukrainian society are explored. It is stated that the identity of Ukrainian Orthodox believers is characterized by the layering of several identities, combining religious and cultural components. The religious component of the Orthodox identity includes rational and irrational experience of comprehending the Christian God and appears as a world-view basis of church-confessional self-determination. For some of believers Orthodox identity means adopting a way of life and a system of values under the influence of which social identity becomes religiously colored. The determining influence of spiritual values on social behavior forms and the independence of these values from the change in political systems makes the main features of the deterministic religious factor of civic identity.

The cultural component of the modern believers' Orthodox identity is based on ideological uncertainty, undeveloped civic consciousness, globalization challenges, ideas about the traditional character of Orthodox identity. Taking this into account, it is determined that for a large part of Orthodox believers self-identification appears not so much through the confession of faith and the adoption of the Orthodox way of life as through recognition of Orthodoxy as a cultural tradition that has historically developed in the country. Awareness of belonging to culture, which stimulates the vision formation of its development ways, means actualization the civic type national identity.

It is established that an important factor in the development of the Orthodox believers' identity in Ukraine is the civilization dimension of the jurisdictional division, the problem of which has not yet been resolved. The main factor determining the development of the believers' identity at the present stage is the creation of a Local Orthodox Church of Ukraine. Belonging to one of the Orthodox jurisdictions will further determine the Ukrainian Orthodox believers' identification model.

Keywords: confessional identity, Orthodox believer, Ukrainian society, tradition, Orthodox jurisdiction, religious community, cultural identity 